\title{
The Disconcerting Popularity of Popular In/justice in the Fizi/Uvira Region, Eastern Democratic Republic of the Congo
}

\author{
Judith Verweijen \\ Researcher, Nordic Africa Institute, Uppsala and Conflict Research Group, \\ Ghent University, Ghent, Belgium \\ judith.verweijen@ugent.be
}

\begin{abstract}
This article analyses the disconcerting phenomenon of 'popular in/justice', or killings of citizens enacted by other citizens 'in the name of justice'. It studies these practices in the Fizi/Uvira region in the conflict-ridden eastern Democratic Republic of the Congo, where they target either suspected criminals or presumed sorcerers. The article locates the causes for this phenomenon in certain transformations of socio-political space, notably the unsettling of customary and politico-administrative authority, dysfunctional state-led justice and security services, and the militarisation of local governance. These developments have compounded dispute processing and handling the occult, leading these processes to often turn violent. They also incentivise and enable politically and socio-economically marginalised yet demographically numerous groups to assert socio-political agency and engage in order-making. The article concludes by arguing that popular in/justice should be seen as an expression of such aspirations to exercise efficacious socio-political agency, thereby constituting a perverse form of democratisation.
\end{abstract}

\section{Keywords}

mob justice - witchcraft - customary authority - youth - eastern Democratic Republic of the Congo 
The phenomenon whereby citizens collectively kill a limited number of other citizens 'in the name of justice' is highly disconcerting. It evokes images of lawlessness and, especially when occurring in an African context, of barbarism and 'irrationality'. Yet, extra-legal popular violence in the name of justice is a phenomenon that can be found across the globe. ${ }^{1}$ Regardless the social mechanisms by which these acts of violence are produced, and the ways in which they are discursively framed, these practices are deeply puzzling both to people living in the contexts where they unfold and outside analysts. What pushes people to 'take the law into their hands' and kill fellow citizens, sometimes their own neighbours?

This article tries to answer this question for one specific context, the territories of Fizi and Uvira located in the province of South Kivu in the eastern Democratic Republic of the Congo (hereinafter the Congo). This area has been plagued by particularly intense dynamics of conflict and violence for well over two decades, and has at present a high incidence of what is called 'popular in/ justice' herein. As explained further below, this term was chosen to indicate that these practices are experienced simultaneously as forms of justice and injustice in the contexts where they occur. The Fizi/Uvira area does not appear exceptional for having a high incidence of cases: in several other sites in the eastern Congo where the author has conducted field research, such as Ituri and Rutshuru, popular in/justice is also a recurring practice. ${ }^{2}$ However, the Fizi/ Uvira region was selected based on the assumption that understanding such a complex phenomenon requires profound contextual knowledge. Given that the author has conducted extensive research in Fizi/Uvira since 2010, it was judged to be the most suitable context for this study. Data were collected in October and November 2014, both by the author and a team of local researchers specialised in popular in/justice. ${ }^{3}$

1 E.g., a recent report on racial lynching in the southern United States documents 3,959 victims between 1877 and 1950. Equal Justice Initiative, Lynching in America. Confronting the Legacy of Racial Terror (EJI, Montgomery, 2015).

2 The author has conducted periodic research in the eastern Congo for various projects since 2010.

3 One team of the Centre Independent de Recherches et d'Études sur le Kivu (CIRESKI), consisting of Oscar Dunia Abed and Paul Sungura Tambwe, conducted research on the LusamboMakobola axis, while the author and Juvenal Twaibu Bilongwe covered Runingu, Kiliba and Uvira town. Open-ended topic guides were used for group and key informant interviews per village/quarter and per case of popular justice. 
Based on the data gathered during the fieldwork, this article explores the main forms and causes of popular in/justice in Fizi/Uvira. In particular, it studies how this phenomenon is shaped by a profound crisis of authority and high levels of local conflictuality, as nourished by limited state effectiveness, militarisation, and the erosion of the authority of customary chiefs and elders. It shows how these transformations of the socio-political order have created space and incentives for groups with limited access to official political channels, in particular youth, to assert socio-political agency. This includes killings and other damage in the name of justice, conceptualised as practices of 'ordermaking'. However, since popular in/justice only further unsettles the political and social order, it reinforces the very conditions in which it thrives.

\section{Shifting Authority Structures and the Rise of the Mai-Mai} Imaginary

The territories of Fizi and Uvira border Rwanda, Burundi and Lake Tanganyika. Reflecting the Kivus' nature as a mosaic of groups designated as 'ethnic', this area is inhabited by dozens of such groups. While Fizi is home to the Babembe, and to a lesser extent to the Banyamulenge, Bafuliiru and several other groups, Uvira is inhabited in majority by the Bafuliiru, but also by the Bavira, Banyamulenge, Barundi and others. While the Fizi/Uvira area has been a periodic hotbed of armed activity also before and during colonial times, it is the immediate post-independence forms of armed mobilisation that inspire current manifestations of armed group activity most directly. Soon after the Congo's accession to independence in 1960, revolutionary fervour swept the country. It found its first foothold in the east in the Uvira region, giving rise to the Simba rebellion. The constellation of forces that this insurgency drew upon bears resemblance to the drivers of conflict and violence today, especially the manipulation of youth by politicians, contestations around positions of local, often customary, authority, and the salience of discourses of autochthony. The first unrest was triggered by freshly elected provincial Member of Parliament (MP) Musa Marandura, who mobilised youth to agitate against the mwami (customary chief) of the Bafuliiru, accused of complicity with the disliked colonial authorities and of having ceded a part of the Bafuliiru's ancestral territory to the Barundi. ${ }^{4}$ This last group was portrayed as intruders from neighbouring Burundi who had unjustly been granted a chefferie (customary chiefdom) by

4 B. Verhaegen, Rébellions au Congo (Tome 1) (CRISP, IRES and INEP, Brussels and Leopoldville, 1966). 
the colonial authorities. Such accusations were strongly informed by discourses of autochthony, which posit a dichotomy between, on the one hand, 'sons or daughters of the soil'/natives and, on the other hand, foreigners/outsiders. In the Congo, the figure of the foreign 'other' has often been projected onto Rwandophone groups (speakers of Kinyarwanda and related languages like Kirundi), including the Barundi. ${ }^{5}$

Similarities between past and present can also be found in relation to armed mobilisation. The combat success of what came to be known as the rebellion of the Simba (lions in Swahili, the primary lingua franca in the eastern Congo) ${ }^{6}$ resided to a large extent in combatants' fearlessness, which was partly a result of their belief in battlefield invincibility. Specialists in the occult played an important role in the insurgency, making fighters seemingly untouchable from bullets by tattooing and injecting their bodies with a magical potion (dawa, meaning 'medicine'), and sprinkling it with purifying water (mai or mayi). Provided they respected the strict codes of conduct, these rituals were believed to give fighters a strength similar to the mythical revolutionary figure of Pierre Mulele, causing the Simba's main battlefield cry to become 'Mai Mulele!. However, claims to spiritual powers were also used to establish social control over the population, including via the manipulation of accusations of ulozi or uchawi (sorcery).

The interchangeably used terms ulozi or uchawi (locally also pronounced as bulozi or (b)urozi and buchawi) are commonly translated as 'sorcery' or 'witchcraft'. Yet these are poor and heavily normatively loaded designations for a complex and dynamic system of beliefs and rationalities related to overlapping spiritual and healing powers. The boundaries between ufumu (healing), ulaguzi (divination) and ulozi (sorcery) are porous, ${ }^{7}$ just as those between various spiritual, including religious, and worldly powers. ${ }^{8}$ But whatever the medium or practice, where such powers are believed to be harnessed for harmful deeds, they are commonly recognised as ulozi, the principal term that is employed herein (and mulozi, singular and balozi, plural to designate the person practicing it, hence the 'sorcerer' or 'witch'). In various historical periods, Fizi/Uvira experienced a pronounced rise in both accusations of $u$ lozi and killings related

5 S. Jackson, 'Sons of Which Soil? The Language and Politics of Autochthony in Eastern DR Congo', 49:2 African Studies Review (2006) pp.95-124.

6 All foreign words employed herein that are not in French are in Swahili, when not mentioned otherwise.

7 E. Wild, “Is It Witchcraft? Is It Satan? It Is a Miracle." Mai-Mai Soldiers and Christian Concepts of Evil in North-East Congo', 28:4Journal of Religion in Africa (1998) pp. 450-467.

8 P. Geschiere, The Modernity of Witchcraft: Politics and the Occult in Postcolonial Africa (University of Virginia Press, Charlottesville and London, 1997). 
to this phenomenon, often in times of turbulence and shifting patterns of authority.

One such period are the First (1996-1997) and Second (1998-2003) Congo Wars, which led to the mass mobilisation of armed groups. Former cadres of the 1960s Simba insurgency initially played important organising roles in these groups, leading to continuities in modes of operation, including the employment of purification and protective practices revolving around dawa and mai. Consequently, these groups became known as 'Mai-Mai', a designation that continues to be applied to armed groups that engage in such rituals and employ discourses of autochthony and autodéfense (self-defence). The emergence of dozens of Mai-Mai groups triggered important shifts in local authority structures. Mai-Mai leaders became new figures of authority, whose power was grounded not only in their capacity to wield force, but also in a complex mix of legitimising discourses. These included syncretic notions of Christianity and spiritual powers, discourses of autochthony, ethnicity and autodéfense, narratives of nationalism and patriotism, ${ }^{9}$ and in some cases, messianism, particular strands of which emphasised the nexus of violence and liberation/moral regeneration. ${ }^{10}$ As the Second Congo War progressed, Mai-Mai leaders built up increasingly autonomous financial and support bases. This reduced their dependency on and accountability towards customary chiefs and other local civilian leaders, whose power they usurped by exercising security, justice and fiscal functions. ${ }^{11}$ As a result, violence became an important tool of regulation and the processing of disputes, including those of a more private nature, like family conflicts and personal rivalries.

Another development undermining customary authority was the gerontocratic reversal triggered by the rise to power of the Mai-Mai's youthful rank and file. Together with changing patterns of land distribution and use, the progressive decline of the Mobutist state system and the economy from the mid-1970s onwards led to the pauperisation of youth. As a result, they were no longer able to gather sufficient means to pay mali (dowry), a precondition for a recognised Militia' in A. Arjona, N. Kasfir and Z. Mampilly (eds.), Rebel Governance in Civil War (Cambridge University Press, Cambridge, forthcoming 2015).

10 F.D. Amuri Misako, La symbolique de la légitimation de la violence milicienne en Afrique: Continuités et réinventions du messianisme nationaliste chez les maï maï du Maniema au Congo-Kinshasa (Éditions universitaires européennes, Saarbrücken, 2012).

11 F. Van Acker and K. Vlassenroot, 'Les “maï-maï” et les fonctions de la violence milicienne dans l'est du Congo', 4 Politique africaine (2001) pp. 103-116. 
marriage that renders young men full members of 'the community'.12 Consequently, impoverished male youth were confined to the liminal space between adolescence and adulthood. This generated frustrations that fed into diminishing respect for established forms of authority at the community, village and household level, including that of the bami (plural of mwami) and vieux-sages (village elders). ${ }^{13}$ The proliferation of Mai-Mai groups, who both depended on and subverted local social and political orders, starkly reinforced these developments. Empowered by the gun and developing new militarised forms of social identification, Mai-Mai combatants were increasingly disconnected from and unaccountable to civilian authority. ${ }^{14}$

The 2002 peace agreement signed in Pretoria, marking the formal end to the Second Congo War, did not herald an end to armed group activity in Fizi/Uvira. Many Mai-Mai groups and associated political-economic networks refused to dismantle their military capacities and have therefore continued their activities, although often with changing composition and leadership. ${ }^{15}$ This has been both a cause and a result of ongoing insecurity, which is also sown by foreign rebel groups operating on Congolese soil and the ill-behaved Forces Armées de la République Démocratique du Congo (FARDC), the national armed forces. Rampant insecurity has additionally prompted the formation of villagebased armed vigilante movements and urban-based groups of balala rondo (from ku-lala, to sleep in Swahili, while doing la ronde, or patrol, in French). These are unarmed youth vigilante groups who conduct nocturnal patrols and often have a quasi-official status, implying they are sanctioned by the chef $d e$ quartier (lower-level urban authority) and collaborate with the security services.

While armed forces are numerous, clashes between them are not as important a source of violence as their engagement in revenue-generation activities and their efforts to maintain social control. Banditry, especially coupures de

12 The term 'community' is approached herein as an imagined collective that informs modes of social identification and exchange. Social agents are part of multiple, often overlapping, and ill delineated communities, which do not automatically generate forms of solidarity nor preclude important power and socio-economic differentials.

13 K. Vlassenroot and F. Van Acker, 'War as Exit from Exclusion? The Formation of MayiMayi Militias in Eastern Congo', 17:1-2 Afrika Focus (2001) pp. 51-77.

14 L. Jourdan, 'Being at War, Being Young: Violence and Youth in North Kivu' in K. Vlassenroot and T. Raeymaekers (eds.), Conflict and Social Transformation in Eastern DR Congo (Academia Press, Gent, 2004) pp. 157-176.

15 M. Eriksson Baaz and J. Verweijen, 'The Volatility of a Half-cooked Bouillabaisse: RebelMilitary Integration and Conflict Dynamics in the Eastern DRC', 112:449 African Affairs (2013) pp. 563-582. 
route (flash ambushes) and violent robbery, is rampant in both rural and urban areas, and is believed to be authored by changing coalitions of armed groups, deserters, professional bandits, local youth, demobilised, and members of the security forces, who often also protect and organise the activities, for instance by distributing arms. The security services are also at the root of a range of other forms of violence, including unlawful arrests, extortion, or violent interventions in disputes, sometimes at the request of civilians wanting to harm their adversaries. Reflecting the militarisation of local governance, it has become common practice to solicit armed actors for dispute processing and score settling, either against payment or in the framework of protection arrangements. ${ }^{16}$ Due to soaring arms circulation and rampant un-and under employment, such 'guns for hire' are not difficult to find. It is in this violent environment that popular in/justice takes place, constituting only one among a range of types of violence.

\section{Patterns of Popular In/justice in Fizi/Uvira}

Popular in/justice in Fizi/Uvira often takes the form of stoning or beating people to death and/or burning them alive, and is commonly accompanied by acts of property destruction, like incinerating houses and belongings. For the year 2014, the non-governmental organisation (NGO) CIRESKI registered 43 cases, of which 26 resulted in death and 17 concerned persons who were targeted but escaped. ${ }^{17}$ This represents a decline from the 57 cases recorded during the year 2013. ${ }^{18}$ Of the 43 persons targeted, 22 were women and 21 men, while the majority of victims were wazee (elderly persons, over $5^{0}$ years of age). Cases occurred both in rural and in urban settings, but were unequally spread. This points to locally specific circumstances that activate such killings, but also to differences per ethnic group. In the following, the nature of this phenomenon is further studied, first by reflecting on how it should be designated, and then by a discussion of its underlying mechanisms.

16 M. Eriksson Baaz and J. Verweijen, 'Arbiters with Guns: The Ambiguity of Military Involvement in Civilian Disputes in the DR Congo', 35:5 Third World Quarterly (2014) pp. $803^{-820 .}$

17 CiReski, "Statistiques Annuelles de Cas de Justice Populaire Uvira/Fizi. Année 2014", Unpublished document, 2015.

18 Interview members of CIRESKI, Uvira, 2 November 2014. 
3.1 The Terminology Conundrum

When studying extra-legal killings of citizens enacted by other citizens in the name of justice' in Fizi/Uvira, it soon became clear that these violent practices were difficult to label. In the course of 2013, when the authorities intensified efforts to crack down on these practices, including by arresting a number of perpetrators, the modus operandi started to change. Where previously a crowd was mobilised to collectively kill, which clearly exposes the perpetrators, those wanting to rid of persons seen as harmful now started to appeal to armed actors to simply shoot them. This highlights the fluid boundaries between this phenomenon and other forms of murder, and casts doubts upon the adequacy of existing terminology. For instance, the term 'mob justice' suggests clear boundaries with other types of violence not committed by mobs. Moreover, it puts too much emphasis on the agency of the crowd, thereby obscuring that the decision to kill was often made by a limited number of persons, not uncommonly family members or neighbours.

The word 'justice' is no less problematic. A polyvalent and strongly contextbound notion, 'justice' is often held as an ideal. As such, it is juxtaposed to the less ideal solutions to conflicts, harm and grievances found in everyday life. This includes practices of popular in/justice, which are often regarded with profound ambivalence. For Lombard and Batianga-Kinzi, this casts doubt on the extent to which these acts constitute 'justice'. Therefore, they label these practices 'popular punishment'. ${ }^{19}$ Yet, the term 'punishment' does not capture the sense of purification and of what Allen and Reid have called "social cleansing" 20 that accompanies acts that are sometimes seen as 'justified' and even as 'doing justice'. It also does not reflect how a wider sense of injustice, related to deep socio-economic and political inequalities as well as arbitrary state interventions, tends to be a driving force behind these killings, which has prompted Godoy to situate these forms of violence in the semantic framework of 'popular injustice.' ${ }^{21}$ Locally employed vocabulary offers no way out of this terminological conundrum. Neither the Swahili expression kujihamuliya sheria (to administer justice oneself) nor the French justice populaire capture the ways in which these practices are locally phrased, which is often by simply describing the act. For these reasons, despite its imperfections, it was decided

19 L. Lombard and S. Batianga-Kinzi, 'Violence, Popular Punishment, and War in the Central African Republic', 114:454 African Affairs (2015) pp. 52-71.

20 T. Allen and K. Reid, 'Justice at the Margins: Witches, Poisoners, and Social Accountability in Northern Uganda', 34:2 Medical Anthropology (2014) pp. 106-123, p. 5.

21 A. Godoy, Popular Injustice. Violence, Community, and Law in Latin America (Stanford University Press, Stanford, CA, 2006). 
to employ the term 'popular in/justice', reflecting the character of this phenomenon as being simultaneously experienced as and driven by forms of justice and injustice.

The term 'popular' was considered appropriate, as these practices have two 'popular' dimensions. First, the target is seen as having not only harmed a single person or family, but 'the community' as a whole. Therefore, it is believed to be in the interest of this larger group to 'neutralise' the threat. This relates to the second dimension, namely that the act of killing is executed or approved by a large number of people. In this context, 'approval' should be seen as a complex notion that is not irreconcilable with the feeling that 'this is not how things should be'. It is not uncommon to hear people express strong regrets after the act, like watu balisikitika tu (people only had regret) or kuuwa watu ni mubaya (it is bad to kill people). However, popular in/justice is sometimes also considered to be a necessary evil. This is reflected in justificatory expressions that were captured during the fieldwork, such as hatuna amani (we are not in peace); uyu mutu alishauzuru na urozi (that person has exaggerated with ulozi), tunachoka na huyu mutu (we are fed up with this person), anatesa batu (he or she is vexing people). Such discourses point to forms of popular approval that are at least partly inspired by notions of social cleansing and of what Kyed calls "order-making", referring to inherently political 'policing'-like practices that try to create, maintain, transform and define 'social order. ${ }^{22}$

Popular in/justice is sometimes also seen as justified in the face of dysfunctional state institutions, reflecting notions of autoprise en charge (taking care of oneself) that inspired coping practices in the later Zaire era (1980s-199os), when the economy and public service provision crumbled. This gave rise to the idea, further popularised through the notion of autodéfense that is central to the Mai-Mai imaginary, ${ }^{23}$ that where the state fails to live up to its basic tasks, the popular usurpation of state functions is justified. Furthermore, in certain instances, popular in/justice is considered simply a deserved punishment. This is most obviously the case for the instigators, who are often driven by revenge, and for the perpetrators, commonly motivated by considerations of social cleansing. Yet it may also apply to bystanders, in particular when it concerns suspected bandits. Nevertheless, opinions are commonly divided and feelings profoundly ambivalent, as captured in the term 'popular in/justice'.

\footnotetext{
22 H. Kyed, State Recognition of Traditional Authority, Citizenship and State Formation in Rural Post-War Mozambique (PhD Diss, Roskilde University Centre, 2007) p. 6.

23 J. Verweijen, 'From Autochthony to Violence? Discursive and Coercive Social Practices of the Mai-Mai in Fizi, Eastern DR Congo', African Studies Review, forthcoming 2015.
} 


\subsection{Categorisations and Mechanisms}

The cases of popular in/justice analysed for this study fall into two broad categories. The first relates to killings of (suspected) bandits and is often targeted at those caught in the act and recidivists believed to be involved in recently enacted crime that provoked moral outrage. This may be either due to the nature of the offense, like the rape of a minor, or the nature of the victim, such as a locally well-known and popular figure. For instance, in February 2011, six presumed bandits were burned alive in the Kakombe quarter of Uvira, shortly after a popular economic operator had died in a violent robbery. Dealing in spare parts for motorcycles, and always willing to sell on credit, Mr. Wangili Kabwe was highly appreciated among local youth, many of whom eke out a living as a motard (motor-taxi driver). Therefore, youngsters were quick to mobilise and capture what were believed to be the members of the banditry ring responsible for his death. However, most cases fall into the second category, concerning incidents that are discursively framed as revolving around accusations of ulozi (sorcery). Suspicions of ulozi frequently surface in the case of sudden, unexpected deaths, in particular of young people, which are often seen as 'unnatural'. Many informants emphasised that it is common to search for the cause of someone's death by consulting wafumu (traditional healers, sometimes also called watahalamu), or when the death seems very suspect, a mulaguzi (seer). Balaguzi employ a system called lusegejo in Kifuliiru (the language of the Bafuliiru), described as a procedure whereby the medium consults spirits via a 'traditional telephone', which allows for identifying the author of the evil. Most of the times, the latter are family members or neighbours. As an informant explained: "Here in Africa, we say: 'someone who does not know your family, cannot bewitch you', so witchcraft takes place in the immediate family". ${ }^{24}$ Hence, in relation to popular in/justice it was often remarked that yote inatoka ya jamaa (it all comes from the family). Yet, as the fieldwork showed, many victims were neighbours rather than family members of the instigators.

Whether family or not, the persons targeted were often believed to be involved in disputes with the instigators, for instance related to inheritance, marriage, property, or personal enmity. However, such antecedents could not be identified in all cases, in particular where suspicions of ulozi had circulated for a long time, or the capacity to mobilise bad spirits was believed to be hereditary. Such long-standing suspicions of ulozi were mostly directed against elderly women, reflecting the belief that "ulozi is primarily the domain of

24 Interview member of comité des sages, Uvira, 4 November 2014. 
women" although "men can borrow it from women". ${ }^{25}$ According to members of local women's organisations, these beliefs should be seen in the light of the overall position of women in Congolese society, who are portrayed as lacking akili (wit, intelligence), but also as being hatari (dangerous). Yet, these informants also emphasised that women are by no means only victims of popular in/justice. Many women are actively involved in making the accusations that usher in the killings. ${ }^{26}$ Such accusations often circulate for a while before the actual killing takes place, implying that while the moment of death generally comes as a surprise, death itself was already in the air.

\section{Understanding Popular In/justice in Fizi/Uvira}

Popular in/justice in Fizi/Uvira is by no means a recent phenomenon. Killings of both suspected criminals and balozi are reported to have also occurred in the Mobutu era and before, mostly through what is called système ya kachoma (system of burning alive). However, it is commonly believed that cases have augmented. A first step toward exploring the reasons for this perceived augmentation is to analyse what people in Fizi/Uvira themselves identified as the main causes. When asking why popular in/justice occurs at such a large scale, the most often-heard response was zaifu ya l'état (the weakness of the state). In the eyes of many, people are pushed to 'take the law into their own hands', due to a corrupt justice system and rotten security services that are not able and willing to do their job. Another frequently mentioned reason was that there has been a sharp rise in conflicts, ascribed to factors like massive war-related displacement and returns, conflicts between cultivators and cattle-herders, and chronic poverty, as partly occasioned by ecological degradation, in particular the deforestation of the Plateaux (mountains adjacent to the Ruzizi Plain). What was also commonly cited as a cause was a substantial increase in hatred and a thirst for vengeance, in part ascribed to the legacy of the atrocities committed during the Congo Wars. These vengeful attitudes were believed to contribute to a general degradation of respect for human life and the generalisation of violence. In the words of an informant: "Chickens are of more value than human beings today because when they die, one can eat them". ${ }^{27}$ Together with an increase in sudden deaths due to the population's ill state of health and deficient access to health care, this general rise in disputes and hatred was

25 Interview civil society activist, Uvira 5 November 2014.

26 Discussion members of local women's organisations, Uvira, 5 November 2014.

27 Interview member of community organisation, Kalundu, 11 February 2014. 
seen to have prompted an augmentation of accusations of ulozi. This was again cited as leading to an increase in popular in/justice, notably through the actions of 'disobedient youth', who were generally ascribed an important role in popular in/justice-related violence.

The multitude of factors underlying popular in/justice invoked by the inhabitants of Fizi/Uvira points to similarities with other contexts where this phenomenon abounds, although these each have also their own specific characteristics. Across settings, popular in/justice surfaces where the following processes are manifested: the unmooring of established authority structures without new forms having become sedimented; the weakening of social cohesion, sometimes as a result of shifting gender and inter-generational relations; and finally, a recent or current period of intense duress, commonly linked to extreme poverty and violence. ${ }^{28}$ In such situations, the social pressures produced by and producing changing patterns of authority compound ordermaking, in particular forms of social regulation like dispute processing, but also policing, tackling banditry and handling accusations of ulozi. Amidst these social perturbations, popular in/justice emerges as an attempt to mark and claim socio-political agency by aggrieved and marginalised groups. This is described by Godoy as a "perverse form of political empowerment", 29 and can be seen as an effort at order-making, including the reparation of the social tissue by means of social cleansing. In the following, these transformations in authority and social structures are further studied, having been regrouped in three categories: the security and justice apparatus, customary and religious authority, and the socio-political agency of youth.

\subsection{A Malfunctioning State-Led Security and Justice Apparatus}

Malfunctioning state-led justice and security services contribute to popular in/ justice in both direct and indirect manners. Due to the peculiar workings of the Congolese justice apparatus, it often occurs that perpetrators are simply liberated at the level of the police or judiciary, either by means of paying or as a result of the pressure of powerful protectors. The porosity of prisons in the Congo allows others to simply escape. As a consequence, it is not uncommon for the same bandits to be caught over and over again. Furthermore, security services regularly fail to intervene in cases of crime, which fosters the impression of lawlessness. This creates a fertile climate for popular in/justice, as people

28 T. Allen, 'The Violence of Healing', 47:2 Sociologus (1997) pp. 101-128; Godoy, supra note 21; Lombard and Batianga-Kinzi, supra note 19.

29 A. Godoy, 'When "Justice" is Criminal: Lynchings in Contemporary Latin America', 33:6 Theory and Society (2004) pp. 621-651, p. 637. 
believe that there are little other options to get rid of bandits. As mentioned, within the context of Fizi/Uvira, such acts also resonate with locally powerful discourses of autoprise en charge (taking care of oneself) and autodéfense.

Hampering justice and security apparatuses also contribute to popular in/ justice by complicating efforts at dispute processing. Handling disputes generally follows slow, lengthy, and often expensive procedures that rarely find an outcome that is accepted by all parties. This fuels a propensity among citizens to appeal to members of the security services or other armed actors to 'resolve' their dispute, sometimes by force. Members of the security services also impose themselves on disputes in an unsolicited manner, even when these fall outside of their sphere of authority. This has led to a profound blurring of the public/private distinction in matters of dispute processing. Both in relation to the labelling of disputes, for example whether they are 'private enmity' or a 'public conflict', and as regards the appropriate channels to address them, the 'public/private' distinction is often difficult to apply and at times hardly relevant from the point of view of those in search of litigation. Persons feeling aggrieved or disadvantaged often simply seek the most accessible, rapid, and suitable channel to address their conflict, regardless official mandates, spheres of authority, and the law. ${ }^{30}$ While it is not clear whether there is a direct relation with popular in/justice, it is not implausible that this pluralisation of dispute-processing practices facilitates similar forceful 'solutions' enacted by people themselves. The same applies to the security services' tendency to arrest or punish people without clear procedures or specified grounds of evidence. Possibly, this has demonstration effects, leading citizens to similarly disregard procedures and standards of evidence when incriminating others. This can also be said in relation to respect for the law more generally, as illustrated by the following question, posed by a local authority: Wakati wakubwa habaheshimie sheria, namna gani baraia bataiheshimiya nabo? (if the authorities do not respect the law, why would citizens do so?). ${ }^{31}$

Another way in which security agencies contribute to popular in/justice is their frequent failure to intervene before, during and after the killing, whether out of fear, incapacity or reluctance, like when they do not care or covertly approve. When present at the scene of the events, under-staffed and underequipped police are often wary to intervene, not only as they risk their own lives, but also as they fear making more victims due to a lack of anti-riot gear, such as rubber bullets or tear gas. For instance, in October 2014, a mass of people killed a man in Sange who had stabbed a young girl to death he had first tried to rape. As the head of the local police explained:

$30 \quad$ Eriksson Baaz and Verweijen, supra note 16.

31 Interview deputy chef d'avenue, Kavimvira, 2 November 2014. 
We shot bullets in the air to disperse the crowd but that did not help. So we decided it was better instead of killing many people to leave them and they killed this guy (...) Our colleagues from the military asked us why we did not shoot at the crowd. I begged them to let justice have its course, but in vain. What could we have done? ${ }^{32}$

What sometimes also plays a role in the security services' hesitation to intervene is the (perceived) tendency of youth engaging in the killing to take dawa to immunise themselves against bullets fired by the security services. As the same policeman testified: "It were especially youth, and the youth were already blinded by their gris-gris [amulets]".33 This shows how popular in/justice is facilitated by the Mai-Mai imaginary, as its beliefs in invincibility instil fearlessness in those executing it.

The fear for the crowd, or rather popular opinion, also hampers police intervention after acts of popular in/justice. Where the killing of certain persons was widely seen as justified to neutralise threats to 'the community', they fear that efforts to hold the perpetrators or instigators to account will provoke dissent. In certain cases, members of state security services actually approve of the killing, for instance when it concerned a bandit sowing insecurity in their jurisdiction or a suspected mulozi. When inquiring about a certain case of mob justice in the town of Kiliba, a local policeman stated: "Our investigation showed that the woman was a mulozi". 34 Indeed, members of the security services are susceptible to holding the same beliefs as the population, in particular when they have had little professional education and are deployed in their area of origins, like the cited policeman in Kiliba.

But the role of the security services in popular in/justice is not all bleak. Occasionally, they help prevent those targeted from being killed. In particular the FARDC, more numerous and stronger than the police, frequently intervenes. The FARDC also shields potential victims in its camps or bases or allows them to flee. When visiting a battalion commander in Sange, it was found that he was harbouring a muganga wa asili (traditional healer) suspected of having killed his wife. Aggrieved, the latter's family had stated to refuse to bury her body until the suspected perpetrator would be burned alive. The military did not only protect the man, but also organised a consultation between the two families in order for them to reconcile, showing the deep crisis of civilian dispute-resolution mechanisms. ${ }^{35}$

\footnotetext{
32 Interview head of police CIAT (commissariat) Sange, 24 October 2014.

33 Ibid.

34 Interview policeman, Kiliba, 4 November 2014.

35 Interview commander FARDC $1005^{2^{\text {nd }}}$ battalion, Sange, 14 October 2014.
} 


\subsection{Eroding Customary and Religious Authority}

Customary authority has been an integral part of the bifurcated Congolese state since the colonial era, when the colonisers appointed customary chiefs as intermediaries. While in each area and among each ethnic group, customary chiefdom is shaped differently, a few traits appear generalised. Chiefs are commonly believed to have privileged contact with mizimu wa mababu (the spirits of the ancestors of a certain community). Together with other spiritual powers, this provides them with the authority to deal with ulozi. However, the fieldwork findings indicate that customary chiefs' authority in these matters has been eroded, leading people to bypass them and go directly to walaguzi (seers). In the past, people suspecting others of ulozi would first consult the elders and local chiefs (at localité level), who would try to resolve the case by convening the accuser and the accused. This would also serve as a warning to the suspected mulozi, who was thereby given the occasion to stop their harmful acts and reconcile with the opposing party. When this would not work, cases were referred to customary authorities at groupement level, where they were commonly treated by the customary court (of second instance). This court would again refer irresolvable cases to the customary court of the chefferie, which often sent the accused to do an ulozi test conducted by seers designated by the mwami. For the Bafuliiru, this procedure, which is called kihango in Kifuliiru, takes place in Lemera, the seat of the chefferie. It consists of a variety of tests, like asking the suspect to pick a stone from the bottom of a pot with boiling water to see whether they burn their hands, or putting a nylon thread on a metal plate that is heated with fire, in order to see whether it breaks. Where suspicions of witchcraft are apparently confirmed, the suspect is excommunicated and has to move to a different place. This type of expulsion does not exclude return at a later stage, when it is believed that the person has abandoned the occult, although this was said to be quite rare. While seemingly effective for dealing with matters of ulozi, the kihango procedure is increasingly bypassed. One of the reasons is the elevated cost, as the average price for both the accuser and the accused is that of a cow (approximately 150 USD), with an additional 50 USD as 'guarantee', to be paid when the accusation is seen to be verified. Furthermore, Lemera is far away, being located up in the mountains, especially for the Bafuliiru living in the town of Uvira. Therefore, many people go to seers who are not designated by the mwami, but are reside near-by, although these often also demand hefty financial compensation. However, such non-official seers are not always completely trusted, and are believed to be easily corrupted by balozi. Hence, a number of cases of popular in/justice were found where people had been declared innocent on the basis of the test, but the results had been rejected. 
Chefferie-authorized ulozi tests have also been undermined by the suppression of customary courts after the establishment of the Tribunal de Paix (Tripaix) in Uvira in 2007. The Tripaix is a lower-level court that can hear crimes punishable up to five years of prison. The suppression of customary courts was a process that was already initiated under Mobutu, but that has been unevenly applied. ${ }^{36}$ While intended to bring justice closer to the people and to increase accountability, in practice, the suppression of customary courts has made justice less accessible and the judgment of customary matters more difficult to control. While customary courts had a presence at groupement level, people now need to travel all the way to Uvira. Furthermore, the Tripaix's chamber for customary affairs, in which the judge is assisted by three assessors specialised in the customs of the particular ethnic group involved, is reported not to work in an adequate manner. Additionally, since Congolese law does not recognise ulozi, this chamber is not authorised to deal with these cases. Therefore, the mwami of the Bafuliiru decided to reinstate kihango in 2009. Yet, this has not occurred for other ethnic groups, who therefore have to rely on 'private' seers. Especially where the price of consultation is relatively low, this may attract large numbers of people. For instance, among the Babembe living on the Swima-Makobola axis, it has become almost standard practice to consult after each death the mulaguzi that is commonly called ' 25 ', who is established in the Matata quarter in Baraka. Reportedly, this seer only asks 25.000 Francs Congolais (CDF, approximately $27 \mathrm{USD}$ ), which explains a part of his popularity. This appears to have had an enkindling effect on popular in/justice, since the majority of cases in this area involve persons allegedly identified by the 25 .

Aside from accessibility and costs, customary chiefs are also increasingly bypassed due to their perceived loss of competence to deal with ulozi. Many informants professed the belief that not only has its incidence increased, new and more deadly techniques are employed that established mechanisms cannot deal with. The widespread displacement of people during the wars is seen to have brought them into contact with new types of ulozi, in particular in countries regarded as hotbeds of the occult like Tanzania. A former judge of the customary tribunal of Runingu explained:

Youth travel a lot to other countries and areas, where they learn other types of witchcraft like mulonge. This is a deadly black powder and if you step

$36 \quad$ K. Tekilazaya Defi et al., République démocratique du Congo. Le secteur de la justice et l'état de droit. Un état de droit en pointillé. Essai d'évaluation des efforts en vue de l'instauration de l'état de droit et perspectives d'avenir (Afrimap/Open Society Initiative for Southern Africa, Johannesburg, 2013). 
over it, your feet, leg starts to become swollen and you become ill. This previously did not exist among the Bafuliiru, it was brought from the Barega. ${ }^{37}$

The efforts of churches to deal with ulozi and popular in/justice are also believed to have become less effective. Similar to other contexts, ${ }^{38}$ churches in Fizi/Uvira tend to reinforce beliefs in the occult, as religious leaders double as seers/healers, and as efforts to reduce these beliefs reconfirm their existence and enhance their symbolic efficacy. ${ }^{39}$ In the words of a civil society activist:

The churches try to reduce this [popular in/justice], they preach love for our fellow creatures, but there is also sometimes confusion in the prayer room. There are also priests who behave like marabous, who give off messages that identify the authors of evil, this reinforces accusations of sorcery [sorcellerie.$^{40}$

Interestingly, the fieldwork findings showed that it was commonly believed that balozi banajificha mu kanisa ('hide in the church'), implying they pretend to be devout Christians, which is the majority religion in Fizi/Uvira. ${ }^{41}$ Indeed, several of the victims were relatively active in local churches, for instance being the head of the women's chapter of the 8ème CEPAC (Pentecostalist church), or in one case a pastor, which shows that those targeted are not always among the most marginalised. Churches' capabilities to address popular in/justice are also believed to have been undermined by religious pluralisation. The wide heterogeneity of churches and sects causes a decreasing amount of religious leaders to have moral authority in communities as a whole, rendering it more difficult for them to reconcile parties and devise solutions that everyone abides by.

Yet, the relative efficacy of church interventions appears to highly differ per ethnic group, depending on the standing of the churches. For instance, among the Banyamulenge, a group that lives mostly on the Plateaux and in the town of Uvira, cases of popular in/justice are very rare. One reason is that churches play a proactive role in handling accusations of ulozi. When there are indications, it is common to consult abayumbe (in Kinyamulenge, but derived from the Swahili word ujumbe, messenger) who are a type of seers/intercessors, but

37 Interview former judge customary tribunal, Runingu, 3 November 2011.

38 Allen, supra note 28.

39 N. Eggers, 'Prophètes, Politiciens et Légitimité Politique', 129 Politique Africaine (2013) pp. 73-91.

40 Interview civil society activist, Uvira. 5 November 2014.

41 Although an important Muslim minority exists in this part of the Kivus, in none of the cases studied, suspected balozi were believed to 'hide' in Islam. 
connected to the church and believed to be animated by the Holy Spirit. If the abayumbe conclude that there has indeed been manipulation of bad spirits, a lengthy and intense process of prayer and reconciliation follows. When this fails, those believed to have fallen victim simply move to another village, possibly reflecting the Banyamulenge's (semi-)nomadic past. ${ }^{42}$ While the practice of moving is reported to have diminished, cases of popular in/justice continue to be very rare among the Banyamulenge in comparison to other groups. Informants ascribed this to the comparatively bigger weight of the elders and churches among the Banyamulenge, as well as their higher level of cohesion, at least among sub-groups. ${ }^{43}$ This provides strong evidence for the importance of authority structures and social cohesion in explaining the occurrence of popular in/justice.

\subsection{Manipulating and Manipulated Youth}

While the accusations leading up to popular in/justice usually stem from family members and neighbours, the actual killing is often largely carried out by what are described as vijana, those between $16-35$ years old. As a result, where the targets are the elderly, which is the majority of cases involving accusations of $u l o z i$, the events obtain a strong undertone of intergenerational tensions. This feeds into widespread discourses about the rebellious and dangerous character of present-day youth. Such discourses should be approached in a careful manner, since complaints about disobedient youth are possibly as old as humanity itself. Furthermore, 'youth' is a heterogeneous category, and most people also highlighted the positive dimensions of the current generation, for instance that they contribute to security in the form of the balala rondo. Yet the perception that youth is rebellious and problematic is very tangible:

Youth have changed their mentality ... The majority are mavutabangi [cannabis smokers] and balevi [drunkards]. Nowadays you can buy kanyanga [local brew] openly at the market, in the past this was not the case ... They are easy to incite. ${ }^{44}$

A village elder explained: "Youth do not listen to us anymore. When we give them advice, they accuse us, saying umeshakula [literally, 'you have already eaten', implying, 'you have already been corrupted']".45 Youth were also

\footnotetext{
42 Interview civil society activist from Bijombo, Uvira, 2 November 2014.

43 Interview civil society activist from Marungu, Uvira, 3 November 2014.

44 Interview vieux-sage, Runingu, 3 November 2014.

45 Interview vieux-sage, Runingu, 3 November 2014.
} 
described as 'being above the law/everyone', 'untouchables', and 'in search of/ having taken over power'.

For their part, youth emphasise that they revolt against the older generations, who are held responsible for the dire situation in which the Congo has plunged. The chant that youngsters in the Tanganyika sector of Fizi sing whenever engaging in popular in/justice is telling in this respect: Leo jo leo, kazi tuliotumwa na mzee tunamaliza (today, it is today, we will finish the work [i.e., ulozi] that was sent by the old person). Hence, this standard motivational song for killing highlights the advanced age of the victim. Such anti-elderly rhetoric was also found in other places, and was often connected to discourses of resistance against authority and the established order in general, which the elderly are closely associated with. In an extreme case, youngsters in the village of Makobola II declared during a group interview: Inafaa kuuwa wazee juu vijana waishi kwa amani (we have to kill the elderly, so youth can live in peace). ${ }^{46}$ More common were discourses highlighting the right of youth to chase away the authorities when proven corrupt. Youngsters in Kiliba explained: "Our authorities will not listen, only if you use force. Here [in the Congo] you have to impose yourself in order to realise something. They only understand the language of force". ${ }^{47}$ Denunciations of the authorities do not merely rest at the level of discourse. Especially in the Ruzizi Plain, there have been a string of incidents whereby crowds, often with youth at the forefront, have chased away and attacked local authorities. In July 2014, the chef de cité (urban authority) of Sange was chased out of his office by an angry crowd, who accused him of the anarchic distribution of land titles and the protection of a banditry ring. They took away his cachet (stamp, which is an important symbol of authority in the Congo) and handed it over to his secretary, forcing him to leave his function. Youth in neighbouring Kiliba portrayed this event as a victory for democracy: "This is the reality of the Plain, if the population takes a decision, you cannot stop her (...) Are you aware of the situation in Burkina Faso? ${ }^{48}$ When there is a popular mass, you cannot master it". ${ }^{49}$ It is not only discourses of anticorruption that inspire youth to chase authorities away. In many cases, there are clear undertones of autochthony as well, leading Fuliiru youth to turn against non-Fuliiru authorities seen as outsiders that impose themselves on

46 Group interview local youth, Makobola II, 4 November 2014.

47 Interview local youth, Kiliba, 4 November 2014.

48 Reference is made to the uprisings in Burkina Faso in October 2014 that aborted plans by incumbent Compaoré to extend his stay in power, and eventually forced him to abdicate.

Interview local youth, Kiliba, 4 November 2014. 
the 'natives'. This is clearly exemplified by the protests in Kiliba against the appointment of a new non-Fuliiru head of the hospital in September 2014.

In another incident, which took place in Luberizi in April 2014, youngsters tried to replace a local notable, arguing during a meeting convened to discuss the matter that they were in the majority and that tuko mu démocratie (we are in a democracy). ${ }^{50}$ The vieux-sages and others found this behaviour scandalous, since only the customary chief has the authority to appoint notables. Furthermore, the youth most vocal about the replacement were known to be civilian collaborators of the Mai-Mai group of Simusizi. The same evening, this group kidnapped a person who had protested against the deposition. A salient dimension of this incident is that the notable who was targeted was known as a 'moderate' in the long-standing conflict surrounding the chefferie of the Ruzizi Plain, which pits the Barundi against the Bafuliiru. This conflict was reignited in 2012, when the mwami of the Barundi was assassinated. In order to protest against the appointment of his son and advance Fuliiru claims to the chefferie, Fuliiru politicians, mostly national and provincial MPs, massively mobilised youth in the Plain. Not only did they encourage them to engage in demonstrations and protest actions like blocking the road, they also intervened whenever youth were arrested or suspected of collaboration with the Mai-Mai groups declaring to defend the rights of the Bafuliiru against the Barundi. Furthermore, they incited youth to take action against all authorities seen as 'moderate', implying having a reconciliatory attitude towards the Barundi. The Luberizi incident is therefore indicative of a wider trend, namely the growing importance of the mutual influences between on the one hand youngsters, and on the other hand, politicians and local leaders, two categories who need each other for exercising political agency, although in a manifestly asymmetric manner. It also shows that the power of youth is often partly derived from their tapping into the Mai-Mai imaginary, especially the mobilisation of both worldly and spiritual force in the name of autochthony and autodéfense.

The events in the groupement of Runingu in 2013 further illustrate these dynamics. ${ }^{51}$ In April that year, a woman was burned alive in Kasambura locality, and around 16 houses were set on fire until the security services intervened. Reportedly, these acts were linked to the sudden death of the child of a veterinarian, believed to be the result of ulozi. Shorty after the funeral, rumours started to circulate about the possible authors, and meetings were

50 Interviews various key informants, Luberizi, 13 April 2014.

$5^{1}$ Various interviews in Runingu, including with the ex-chef de groupement, 3 November 2014. 
held left and right, mostly by youth, leading to a list with no less than 84 suspects. In order to prevent further damage, the chef de groupement immediately traced the instigators of this witch-hunt, a number of whom were arrested and transferred to Uvira. However, the effects of these efforts were short-lived. Due to pressures of a number of Fuliiru MPs, the suspects were soon released from prison, and youth now started to accuse the chef of complicity with the balozi. These accusations partly resulted from manipulations by the chef de localité of Runingu centre, eager to take over power over the groupement with the help of a number of powerful MPs. In August 2014, a crowd of around 6o youths attacked the chef de groupement, burning the Congolese flag and taking away his stamp. Giving in to the pressures of the MPS who protected the chef de localité, the mwami of the Bafuliiru eventually suspended the chef de groupement, although he did not nominate the aspiring locality chief. This caused his staunchest supporters among the youth, who had also been most active in the witch-hunt, locally called 'Al Shabaab', to continue to agitate.

While the Runingu episode is exceptional for the direct link between popular in/justice and both local power struggles and higher-level political involvement, it is representative of more general social dynamics. Local authorities and other political actors try to capitalise upon present-day youngsters' thirst to claim and manifest socio-political agency in the face of political and socioeconomic marginalisation, in particular chronic un-and underemployment. Youth have come to play an important role in politicians' on-the-ground power strategies, in part because they are a demographic majority in a situation where 'the mass' has gained in political weight. But the latter's influence does not as much run through official political channels, like elections, as via popular manifestations and attacks on authorities. Furthermore, figureheads among youth have connections to Mai-Mai groups and to political patrons who guarantee them impunity, as evidenced by the frequent release of those apprehended after pressures 'from above'. While this only concerns a limited group, it does set an example for other youngsters, and creates further awareness of their possibilities and right to exert agency. Youth seem especially conscious of their power as a mass, knowing that individually they have little weight. It is only as a mass, and through physical action-such as storming authorities' offices or blocking roads-that they have influence. While popular in/justice is also produced by other rationalities and dynamics, these aspirations for demonstrating and claiming socio-political agency through collective physical action importantly contribute to it. Limited efforts to hold youth accountable for violence further feed into this, as it fosters a feeling of invincibility that is sometimes reinforced by connections to Mai-Mai groups or the use of dawa. 
This relative impunity is a direct result of youth's collective political weight. Aware that having youth turning massively against them will fragilise their power and forego opportunities to harness the collective agency of this group, authorities are often wary of disciplining them. It is telling in this respect that the intensification of the conflict in the Ruzizi Plain in the course of 2012, which rendered Fuliiru politicians dependent on youth to make their extreme antiBarundi standpoint visible, coincided with an upsurge in popular in/justice.

The interacting dynamics of aspirations to exert socio-political agency, ulozi accusations and the Mai-Mai imaginary are also salient among the balala rondo, who play an ambiguous role in popular in/justice. While generally not involved in its execution and sometimes even preventing deaths by intervening, they are reported to importantly contribute to the climate in which popular in/justice surfaces, in particular by validating suspicions of ulozi. Operating at night, balala rondo are generally believed to know siriya (b)usiku (the secrets of the night), including who practices ulozi. This belief is reinforced by their structural use of various types of dawa, including the antiballes (anti-bullets) and anti-ulozi varieties. Consisting solely of resident youth armed with torches, vuvuzelas and in some cases sticks, and operating in an environment where arms possession is elevated, youth vigilantes hardly dare to patrol without these forms of protection, sometimes offered to them by representatives of Mai-Mai groups. Due to this extra power, the balala rondo are seen to be authoritative in identifying balozi. In certain neighbourhoods, like Kavimvira, they were said to abuse this capacity by systematically extorting the people they encounter on the streets at night, threatening to report them the next day as suspected balozi to the local urban authorities. Where this occurs, rumours are brought into circulation that often resurface whenever someone dies in seemingly suspect circumstances. In the town of Kiliba, balala rondo were even alleged to have composed lists of suspected balozi that circulated on radio trottoir, the ever-spinning rumour mill. Such lists are important instruments of power, turning balala rondo - albeit indirectly - into potential arbiters of life and death. While these vigilantes are generally not involved in popular in/justice killings themselves, each time a victim dies that figured on their lists, their power is reinforced. In sum, youth vigilantes contribute to and benefit from the climate that enables popular in/ justice to occur, including by instrumentalising the extraordinary powers they assume through dawa. This further highlights how popular in/justice, and the wider processes surrounding it, serve as a channel for exercising socio-political agency to marginalised groups aspiring to engage in practices of order-making, and how these processes shape and are shaped by power struggles and changing authority structures. 


\section{Conclusion: Counterproductive Order-Making, Perverse 'Democratisation' and Destructive Punishment}

This article has shed light on popular in/justice as it plays out in the conflictridden territories of Fizi and Uvira located in the eastern Congo. It has shown how this disconcerting phenomenon should be situated in a context characterized by different types violence that are separated by permeable boundaries and that are flexibly located on wide public-private, licit-illicit, spiritualnon-spiritual and 'from above' - 'from below' spectra. Similarly, killings related to popular in/justice are informed by multiple rationalities, and evaluated and framed in widely divergent manners. Importantly, popular in/justice is sometimes seen as justified, although opinions always tend to be divided. It may for example be seen as a deserved punishment of recidivist criminals, or believed to restore harmony, peace and order in the community or household, or be seen as a form of autoprise en charge in the face of dysfunctional state institutions.

Like in other contexts where popular in/justice occurs, in Fizi/Uvira, it is strongly related to shifting authority structures, which create both the incentives and space for groups 'to take the law into their own hands'. The waning and transformation of customary, state and religious authority has generated a climate in which the resolution of disputes, whether at the personal, family, neighbourhood or community level, has become increasingly challenging. This includes dealing with accusations of $u l o z i$ and its effects. Various factors compound this, including the decreasing capacity of customary chiefs to handle these matters, the suppression of customary courts, and the pluralisation of religious authority. The resulting general crisis in dispute processing, which is also a product of dysfunctional state-led justice and security services, has increased the appeal of seeking coercive 'solutions', which mostly occurs via soliciting private guns. Yet, in other cases, unresolved conflicts and grudges may enkindle the spread of rumors, and result in accusations related to ulozi. For those diffusing such accusations, as for those effectuating the killings, who are often youth, this constitutes a means of exercising efficacious and meaningful agency, relating to practices of order-making and social cleansing.

Such violent techniques of claiming, demonstrating and exercising sociopolitical agency are also a result of the growing awareness among 'the mass' of its collective power, which partly resides in its importance to politicians. This relates in particular to youth, who claim their place in local societies in an increasingly vocal, and sometimes violent, manner. In this, they are often inspired by techniques and discourses derived from the Mai-Mai imaginary, which historically plays an important role in Fizi/Uvira. Thus, they employ 
dawa and discourses of autochthony and autodéfense. Politicians have capitalised upon these developments by attempting to harness the forceful agency of youngsters for realising their own agendas. However, youth also pursue their own projects, causing manipulation by politicians to sometimes unleash a momentum that the initial instigators are no longer able to control. Popular in/ justice can be seen as one of the by-products of these transformations of socio-political space, serving as a channel through which marginalised yet demographically numerous groups assert socio-political agency and engage in order-making. As such, it essentially constitutes a perverse form of 'democratisation', which draws inspiration from the behaviour of politicians, who tend to manipulate violence in order to reinforce their position. ${ }^{52}$ At the same time, these practices do not merely mimic current leadership; they also comment on, compensate for and revolt against 'the authorities', seen to be at the root of multiple injustices.

However, it is doubtful whether these violent forms of popular agency eventually lead their authors to have more political weight, at least beyond the neighbourhood level. While popular in/justice might reinforce the local position of youth, including vigilantes, this does not give them access to higher levels of decision-making. Furthermore, in combination with other expressions of popular political empowerment, like the chasing away of authorities, it further erodes already waning authority structures. Similar counterproductive effects are found in relation to the desire to restore community harmony via social cleansing. While a temporary unity might be experienced during and sometimes immediately after the act of killing, this moment of experienced cohesion is often short-lived, and opinions frequently turn out to be more divided than in the moment of action. Furthermore, when the instigators are clearly identifiable, popular in/justice tends to generate or intensify vicious conflicts both between and within families, fuelling spirals of revenge. As highlighted by a vieux-sage in Runingu, popular in/justice leads to fitina na chuki (hatred and rancor), ${ }^{53}$ while, in the words of a local authority in Uvira, it also leaves vidonda ku roho (wounds in the soul). ${ }^{54}$ Hence, acts informed by a longing for reparation of the social tissue seem to only further tear it apart.

It can be concluded that while often also driven by other rationalities than punishment, the effects of popular in/justice appear to be largely similar to those of killings that predominantly result from rancor or revenge. This

\footnotetext{
$5^{2}$ K. Vlassenroot and T. Raeymaekers, 'Kivu's Intractable Security Conundrum', 108:432 African Affairs (2009) pp. 475-484.

53 Interview vieux-sage, Runingu, 3 November 2014.

54 Interview deputy chef de quartier, Kakombe, 4 November 2014.
} 
especially applies to the growing amount of cases in which the modus operandi is that of soliciting private guns, which has caused a further blurring of the boundaries with forms of private vengeance. This overlap of popular in/justice and private punishment highlights the fluid, interlocking and mutually reinforcing nature of the different types of violence practiced in Fizi/Uvira: manipulations by politicians interact with violent youth agency and militia activity; private vengeance results from and feeds into popular in/justice and criminality; the engagement of state security services in private score settling and dispute processing erodes their public security functions; and youth vigilantes compensating for these deficiencies derive a part of their efficacy from their capacity to manipulate accusations of ulozi, which again feeds into popular in/ justice. Thus, it appears that the solutions and coping mechanisms that citizens devise to weather a general crisis in justice and security, which reflects a deeper unsettling of the political and social order, only sow further insecurity and injustice, while reinforcing the very conditions in which popular in/justice thrives. 